\title{
HOSTILE RAID INTO DAVIS COUNTY, IOWA
}

\author{
October $30,1922$.
}

D. C. Mott,

Historical Bldg.

My dear Sir:

Replying to your request for information to be published in the AnNals of Iowa, I will say I find both in the governor's office and the office of the adjutant-general, a great many references to the condition of affairs in Davis County, both prior to and after the "Raid," but all the information I find concerning the "Raid" is covered in a twenty-six page report" by Colonel Moore. This is the original report which I hand you with this communication.

Yours respectfully,

C. C. STIL.ES,

Superintendent Archives Division.

A Repon't by Colonel S. A. Moore to Adjutant-General Nathaniel B. Baker

Bloomfield, Iowa, January 1, 1865.

General N. B. Baker,

Adjutant-General of Iowa.

Sir:

In compliance with your request I have collected together the main facts of the recent raid through this county by a band of guerrillas in the month of October last.

While the main features of the sketch are undoubtedly correct, I have no doubt omitted many incidents that would be interesting if collected and related as they occurred.

I have been unable to obtain precise information at what point in our county the raiders first entered. I have conversed with many persons who saw them at different places along the route they traveled, but as their movements were rapid and their stay at each house very brief there is no one who is able to tell the whole story in detail. I am, there-

1Published in part in Vol. II, Report of the Adjutant-General of Iowa, $1804-5$. 
fore, chiefly indebted to $\mathrm{Mr}$. Wallace Power, a young man who was taken prisoner by them and held through the entire route through the county, for the incidents here related.

Twelve young men dressed in Federal uniform, mounted on splendid horses and armed with from two to seven revolvers each, entered the county near the southeast corner, on the morning of October 12, 1864, with two prisoners, young men, whom they had captured in Clark County, Missouri, and riding up to the house of Mr. Gustin, a part of their number dismounted, entered the house and robbed him of a gun, which they broke; a favorite watch, a gift from his father when dying; and about $\$ 160.00$ in money. Another portion of the gang proceeded to William Downing's, broke his gun, robbed him of what money he had in his pocket, and took him prisoner. From Downing's they went to the house of Thomas Miller, from whom they took $\$ 110.00$. They next went to the houses of Neckadier and Chris Waggler, broke Waggler's gun, and passed on to Blough's where they made as they supposed a grand haul in getting a purse of gold, but in reality it was a purse containing twenty-five copper cents and a very small sum in silver coin belonging to a little boy. But they even robbed the child of his pocket knife. Now three of the gang were detailed to go to the house of Mr. William Power, a wealthy farmer living about a quarter of a mile south of Blough's, and rob him. Mr. Power and his son Wallace were working near the road. The old gentleman remarked as he saw them coming dressed in blue uniform, "Wallace, there are some of your soldier friends coming to see you." The young man walked out to the gate to meet them. On riding up they drew their revolvers and ordered him to take off his pants. It was now apparent that they were not his friends, and being unarmed and powerless in their hands, he drew off his "soldier pants" and handed them over. By this time one of the gang was approaching the old gentleman, and ordering him to halt, and threatening to shoot him. But Mr. Power, remarkable for his quiet, pleasant demeanor, not finding a convenient place to halt, kept on the "even tenor of his way" until, dodging behind an outbuilding, broke and ran. The fellow fired at him but missed. Mrs. Power inquired of them who they were, and by what authority they came there. They claimed to be Union soldiers, but she told them that Union soldiers were good men and did not behave in that way. One of them informed her that they were Rebels and bushwhackers, and asked her if she had ever seen any Rebel bushwhackers before. They now proposed to kill the young man unless his father was brought back. And to terrify the young man in compliance with their wishes, they told him that they would kill him in the presence of his mother. He very quietly told them that they had the power to kill him, and that if they intended to do it, he would rather be killed in the presence of his mother than that of any other person. If the fiends had taken his life, could there have been a more appropriate place to die-in the presence of his mother, her whose warm 
kiss first pressed his lips, when resting upon her bosom, should be the last loved one of earth on whom his fading vision should rest.

A younger brother ran down to the field where Mr. Power had gone and told him that they would kill Wallace unless he returned. He then came back. They took Mr. Power's gun and broke it, compelled the father and son both to mount the same horse, without saddle or blanket, taking however from them a saddle belonging to Albert Power, then in the Third Iowa Cavalry, which they carried with them, and started in rapid pursuit of the others who had gone on from Blough's. They did not get Mr. Power's money. They were detained so long with the prisoners that they did not stop to search the house.

They stopped at the house of David Baughman, broke his gun, got some apples and then visited Perry Brown, and broke his gun. They overtook James Brown, formerly of Company B, Thirtieth Iowa, and ordered him to "fall in," a term which he seemed to understand as he obeyed, if not with cheerfulness, with alacrity. They then went to the house of William Millsaps. Some one of the gang remarked, "From the appearance of things, these are poor folks," and proceeded on without stopping to disturb them. They next went to the house of Mr. Reese, took a musket, broke it, and robbed him of $\$ 26.00$. They then went to Daniel Swartzendruver's, robbed him of $\$ 15.00$, five dollars of which amount belonged to Mr. Millsaps, his neighbor, the one they had concluded not to disturb.

It was the first day of the county fair, and Mrs. Swartzendruver had baked some very nice cakes upon which she hoped to take, and no doubt would have taken, a premium. But the scoundrels robbed her of her cakes, and as one of them left the house, turned around, and with his mouth full of cake, shook the stolen "greenbacks" at her, and with a look of defiance rode off to join the gang of desperadoes that, flushed with booty, were becoming ripe for murder.

A great many of our citizens had gone to the fair. They arrested and took prisoner every man who crossed their path. Their movements were rapid as the wind, the main column halting rarely, and then but for a moment, all the robbing being done by details under the direction of their captain, who had perfect control of every member of the gang. You see how difficult it was to obtain any reliable information concerning them. The wildest rumors were current. Every prisoner taken by them was counted as one of the gang. The distance to the county seat from where they first commenced their depredations in the county was some sixteen miles. The rapidity of their movements, the terror they left in their path, the vague uncertain rumors of their numbers varying from fifty to two hundred, the wild dashing novelty of the whole thing, in a county where profound peace had always been, so startled and unnerved even brave men, that a considerable time elapsed before the news reached Bloomfield.

They next stopped at the house of Jacob King whom they robbed of 
$\$ 165.00$, two watches, and some jewelry. They inquired of $\mathrm{Mr}$. King what kind of horses he had. He told them he had some very good ones at the stable, but they were becoming somewhat alarmed about pursuit, and did not stop to get his horses. One of them stopped long enough to adjust a ladies' breast pin before the looking glass, and then rode off to Jeremiah Miller's, broke his gun and robbed him of some \$12,00.

David Gibson was at Mr. Miller's working a short distance from the house at the cane mill. Mounting a horse he came with all speed to town and brought us the first intelligence that we had received of the raiders. But yet he was unable to tell us anything with certainty about their numbers. He counted twenty persons. He was a reliable man, and we were sure that there was certainly twenty. But we afterwards learned that Mr. Gibson had counted the prisoners along with the raiders, not being close enough to distinguish them. Other persons cime in and reported that there were one hundred and fifty of them. We then supposed that those seen by Mr. Gibson were only a detachment, that the main column was somewhere near. A courier arrived who had seen them and reported them one hundred and fifty strong. Another gave the name of a very "reliable gentleman" who had counted one hundred and forty of them in one of the detachments as they filed. around the base of a hill where he lay concealed.

The news soon reached the Fair Grounds, the fair was broken up, men hurried to the town, the arsenal was opened, arms and ammunition were distributed, companies were formed in line of battle, horses were cut loose from wagons and carriages, without reference to who owned them, and mounted by armed men. Couriers were arriving with fresh and exciting news of robbery and murder. An attack upon the town was momentarily expected. Men were placed on the top of houses as a lookout to watch and warn us of approaching danger. Men, women and children were hurrying to and fro, some pale and thoughtful, some flushed and excited. Mothers pressed their children closer to their bosoms. All was hurry, bustle, and confusion. All were willing and vied with each other in getting ready to meet the danger. All past differences were forgotten. A common danger united them. But there was no one to take command and bring order out of chaos. 'The voice of a citizen was heard above the din and confusion proposing that Colonel J. B. Weaver, late of the Second Iowa Infantry, take command of all the militia, and that every man would yield prompt and implicit obedience to his commands. A universal shout of approval rang out along the lines and confidence was seen and felt in the cheerful obedience of every order issued.

A company of mounted men led by Colonel Weaver, who was assisted in the -organization and management of the "raw militia" by Colonel Trimble, started in pursuit late in the afternoon, leaving the command of the militia for the defense of the town to myself, in which I was materially assisted by Captain Gray, Captain Minge, and a large 
number of returned soldiers, whose nerves had been trained to steadiness at Fort Donelson, Shiloh, Pea Ridge, the Seige of Vicksburg, and other fields made glorious by their valor. Beside the farmer and mechanic fresh from the plow and work-shop, stood the heroes who had moved with eye undimmed and cheek unblanched through the smoke of battle, and "the valley of the shadow of death," and gave them words of encouragement and hope. The cavalry under Colonel Weaver is in pursuit of the raiders, as they move westward on their mission of pillage and murder, and we will return and trace them from the house of Mr. Miller some nine miles distant from Bloomfield.

From Miller's they moved rapidly to the house of Mr. Rodgers where they robbed Isaac Smith of $\$ 40$. There they formed the prisoners in line and commencing on the right the captain asked each one separately if they did not want to join his company. They all declined to join him except one whose name was Lewis-one of the prisoners they had taken in Clark County, Missouri. He signified his willingness to join them and was at once clothed in the Federal uniform. The captain made young Power draw off his boots and socks and give them to the recruit. (I learned that Lewis deserted them in Chariton County, Missouri, and came home.) After seeing the recruit "properly clothed," he made a short speech to the prisoners asking a pledge that they would never go into the Federal Army, and then dismissed all of them except Wallace Power, who had been a member of Company D, Forty-fifth Iowa, James Brown of Company B, Thirtieth Iowa, and the other prisoner whom they had brought from Clark County, Missouri. These having been soldiers they refused to release.

They then went to the house of James Paris, took one of his horses out of the plow, searched his house, and found a revolver and watch which they appropriated. They took a gun belonging to Mr. Paris' father, who is quite old, and while in the act of breaking it Mrs. Paris prevailed on them to spare it as it belonged to a very old man who used it for hunting to amuse him in his old age. Strange as it may appear they spared the gun, the first instance of the kind, except one very fine German shot gun which they took with them.

We next find them at William Sterritt's where they broke his gun, but refused to take his money because he had only sixty cents in his pocket book. They went to the house of some one whose name I did not learn, but failing to find any money they took an accordion and made wild music, which if ell as strangely on the prisoners' ears as would a song on the ears of the captive Israelites when they hung their harps on the willows and wept for Zion.

At the house of Loyal Hotchkiss they searched for money, but finding none, helped themselves plentifully at the larder, broke his gun and departed for the residence of Franklin French, who was absent from home, having gone to the fair. They compelled his little son with pistols pointed at his breast to show them through the different apartments 
of the house in search of money. But Mr. French, though prodigal in his loyalty having given four of his family to the cause of his country, is nevertheless a careful man in the disposition he makes of his "greenbacks." He never leaves them "lying 'round loose." Failing to find his money they broke his gun, took a military overcoat, dress coat, a pair of uniform pants, and some woolen shirts.

They then went to the house of Morris McCracken. His son was at home, formerly a member of Company D, Forty-fifth Iowa. They saw his uniform clothing hanging up in the house, and demanded of him whether he had been a soldier. Making a virtue of necessity he told them the clothing belonged to his brother who had gone to the fair, and thus escaped being killed by them. After robbing the father and son of some $\$ 80.00$ and breaking a musket, they left for the house of Mr. Haney. Demanding his money, the old man told them he had none. 'They made a thorough search, tearing things to pieces, declaring that if they found one cent that they would kill Mr. Haney. They failed to find his money, not having searched the old man's pockets, where his greenbacks were quietly resting, and left for the house of Thomas Hardy. Arriving at the house of Mr. Hardy, two of the gang went in, demanded the keys, and commenced a thorough search for money, but in their hurry they overlooked some $\$ 800.00$ which had been placed between the leaves of a day book. The remainder of the gang passed on south about one hundred and sixty yards where they met Mr. Hardy and another person in a wagon. The captain ordered him to halt, and asked him the age of his horses. Hardy replied, "Five years old." "Get out and unhitch them," said the captain, "I want them." "I want them too," replied Hardy, "you don't intend to take them without paying me for them." "I'll pay you for them," said the captain, at the same moment drawing a revolver and firing. The shot took effect near the right eye. The wounded man fell out of the wagon, apparently lifeless, but partially recovering he placed his hands over the wound and while the blood gushed out between his fingers he exclaimed, "God have mercy! God have mercy!" The infernal fiend then dismounted and, drawing a small pistol from his belt, stood over the prostrate form of the dying man and took deliberate aim at his head. The shot from the small pistol not having the desired effect, he muttered between his clenched teeth a curse upon the weapon, replaced it in the holster and, drawing a "Colts navy," fired again. The lifeblood spurted in purple currents from his mangled head, his warm, generous heart ceased to beat, and the spirit of a good citizen, a kind husband and father, stood in the presence of his Maker. After rifling his pockets, in which they found between $\$ 300$ and $\$ 400$, he mounted his horse again and ordered the man who was in company with Mr. Hardy to unhitch the horses, which he did, but they did not stay to take them. Some of his men on coming up to the scene of the murder inquired of the captain why he killed that man. He replied "Because he did not mind me. I will kill any man who refuses to obey me." 
Passing along the road a short distance they met a man from Missouri with a span of horses and wagon, robbed him of his money, near $\$ 500.00$, stuffed it in a cartridge box and coolly asked the gentleman for some cigars. The one who received the money told the man that the captain was coming up and that he must do whatever the captain told him, and to do it quick. The captain upon coming up told the man to unhitch his horses. "Do they pace?" inquired the captain. "No, sir." "Then I don't want them. I have got better horses. Pull off that halter." "Which halter?" inquired the man. "The one on the bay horse." He did it, handed it to the captain, who receiving it told the man to hitch up his horses, drive up to the house and take care of that dead man and not to leave there until morning.

They next stopped at the house of Eleazar Small, a soldier who had served his country faithfully as a member of Company A, Third Iowa Cavalry. Mr. Small, when coming from the barn, saw them approaching and mistaking them for Federal soldiers, stopped to see them. The same soulless wretch whose hands were red with the blood of Hardy rode up to him, asked him a few words about his regiment, and drawing his revolver shot him in the face. He threw up his hands over the wound, and turning around uttered a piteous groan that would have touched the heart of a savage, and received two other shots, one in the neck and the other in the breast. The proud form that had so often faced the enemies of his country in the shock of battle and been spared to return to the bosom of his family, fell lifeless at the feet of an assassin, who coolly dismounting, robbed him of his money.

We next hear of them at Springville. Captain Philip Bence ${ }^{2}$ of Company —-, Thirtieth Iowa Infantry, was at his home in Springville enjoying the society of the "loved ones at home," and a brief respite from the toils and privations of camp life, on leave of absence. The guerrilla chief rode up to the residence of Captain Bence; and calling him out, spoke pleasantly to the captain and inquired about his regiment. The captain was dressed in full uniform. They compelled him to take them off, and to put on a coarse pair of light blue uniform pants and a jeans coat. They then robbed him of $\$ 550.00$ in money and then proposed to kill him. I have been informed that Captain Bence approached the guerrilla chief and in a low tone of voice, that he might not be heard by his family, asked as a special favor that he would not kill him in the presence of his wife.

News of the depredations of this gang having a few moments before their arrival reached Springville, a number of the militia were engaged in getting their horses and equipments. Three or four horses were al-

2Philip Bence enlisted August 13, 1802, as third sergeant in Company $F$. Thirtieth Iowa Infantry, at the age of forty-three. He was a native of Indiana and his residence was Davis county, Iown, at time of enlistment. He was promoted to first lieutenant March 20, 1863, and to captain April 3, 1864. He was slightly wounded at Atlanta, Georgia, July 28, 186.4, and was killed by guerrillis at Springfield [Springvilie], lowa, October 12, 1864. (See Roster lowa Volunteers, Vol, III, p. 1490.) 
ready standing hitched to the fence. The guerrillas captured the horses and took as prisoners Captain Bence, William Hill, David Sanderson, Andrew 'Tunnehill and Joseph Hill. They asked Joseph Hill whether he had ever been a soldier. He said he had not, which was a slight equivocation, for I remember to have seen him performing duty as a faitliful member of Company D, Forty-fifth Iowa. They demanded his money, made him "turn his pockets" and throw away his knife, and then deliberated whether they had not better shoot him because he did not throw the knife farther off. They took his horse however, and mounting the prisoners, Captain Bence and Sanderson on the same horse, rode off.

'They next went to the house of Frank Dabney, saw Mr. Dabney near the door and ordered him to halt, but Frank refused to halt, but went into the house, tossed his pocketbook on the loft and passed out the other door. 'They failed to find his pocketbook, but took his horses. Not far from here they met William Losey and inquired of him if he had heard of any Rebels in the country. He told them that he had and that he was then on his way to Springville and Savannah ${ }^{3}$ to give the alarm and raise the militia. "We are the Rebels," said the captain, "and do you fall in." Losey was astounded and was hesitating. The "click" of a revolver and a word of advice from his neighbors, the prisoners, settled the matter in his mind and he "fell in." They robbed him of $\$ 64.00$.

They now moved rapidly on to the house of Lieutenant William Niblack, late of Company D, Third Iowa Cavalry, whom they robbed of his suber, uniform, and some $\$ 30.00$ in money. They inquired of the lieutenant if he did not think he ought to be killed. It was a grave question. I do not know how long the lieutenant was engaged in "making up his mind,' but I have no doubt he expressed his calm deliberate judgment when lie replied, "No, I do not think I ought to be killed. I have done my duty to my country, and done it faithfully." His life was spared. Why, we can not tell. The fiend whose hands were reeking with the blood of Niblack's neighbors turned away, his hand released its grasp on the deadly weapon at his side. Did one single pang of poignant grief and remorse for his deeds of robbery and murder rend his heart and light up with one ray of conscience the darkness of his soul? It is a secret known only to Him whose "all-seeing eye" sleeps not. The guerrilla chief lingered while the murderous gang passed on. Soon, however, he overtook them and rode forward to the head of the column, and for a short time seemed absorbed in his reflections. The sun was sinking behind the hills. A day of carnage and blood was closing. The avenger of blood was on their tracks. Men who had faced

:Silvannih is still shown on some recent maps. It is two miles west of the center of Davis County, and two miles north of the present Missouri boundary. Springille seems to be extinct, not appearing on recent maps, but old maps show it nearly two miles north of Savinnah-Editor. 
death in the marshes and trenches, in the tangled woodlands and open fields, and toiled and fought their way up the slope of Lookout Mountain above the clouds, were on the "war path." Night was closing around them. 'Their only safety was in rapid flight aided by the darkness. The prisoners would encumber their march. They must be disposed of at once.

The chief reined in his horse and dropped back to the rear of the column and for a few moments rode in silence beside young Power who, suffering from recent sickness and chilled with the night wind, was scarcely able to ride. Soon, however, the chief brightened up and commenced whistling, drew his revolver and, riding forward, placed the muzale near the head of Captain Bence and fired. Captain Bence and Sanderson were both riding the same horse. Both fell off at the crack of the pistol. Sunderson stunned by the concussion supposed for a moment that he too was wounded. Bence raised up on his elbows, put his hands to his facc, and uttered a piteous moan. The cowardly fiend again fired on the dying man. Sinking to the earth in expiring agony, his bosm heaved a few convulsive throls and the beatings of his heart were hushed forever. The following inseription written in pencil was pinned on his clothing:

"Killed in retaliation for David Plunket, who was murdered by Federal soldiers near, Glasgow, Missouri

October 12,1864

By Order of

James Jackson

Lieutenant Commanding."

I learn that a paper bearing the same, or a similar inscription, was found pinned on the clothing of Mr. Small.

'They now held a council to determine what should be done with the remaining prisoners. Deciding to release them, they ordered them to dismount and after extorting from them a pledge not to enter the Union A rmy and not to divulge anything that they had seen until they reached Springville, they dismissed them. The prisoners reached Springville near midnight, fatigued and worn out with the exciting scenes through which they had passed. Young Power was almost exhausted. With nothing on his feet but an old worn out pair of socks which the raiders gave him when they took his boots and socks from him, and without pants, sick and chilled with the night wind, he was near fainting when he reached the house of Dempson Hill where he rested under the kind care of Mrs. Hill until morning.

The expedition under Colonel Weaver struck their trail at Hardy's and followed it with rapidity and unerring precision until they arrived at the place where Captain Bence was killed. It was now 12 o'clock at night, they were in Missouri; five hours behind the raiders to whom every bridle path was familiar. It was impossible to track them. Procuring a mode of conveyance for the body of Captain Bence, they reluctantly retraced their steps homeward. The scene at the residence of Captain Bence when his lifeless form was laid down at the feet of his 
wife and children can not be described. The bruised and mangled heart of his poor wife who had so often leaned her head trustingly like a weary dove upon his manly bosom, sunk beneath the shock and she swooned away. The piteous wail of his little children as they clung to that lifeless form and called it "father," moved the stoutest hearts to pity, and bathed the scarred and bronzed cheeks of the veteran soldiers in tears. God is just, and sooner or later the incarnate fiends, whose crimes of pillage and murder have spread the pall of universal mourning and woe over our people, will meet with their just deserts.

Every preparation that could be made with the means at our disposal was made for the defense of our county seat. The army of Price was said to be on this side of the Missouri River. 'The valley of the Des Moines with its immense supplies of provisions and forage was surely his destination unless met and driven back by the Federal army. The movements of our army seemed about this time to be shrouded in mystery. The approach of Price's invading forces seemed to many simply a question of time. Large raiding and foraging parties could at least be detached from his command and in the absence of well drilled and organized troops, march through the border counties carrying death and desolation to almost every hearthstone. The inhabitants of the county were fully aroused to the importance of the occasion. Companies unarmed and armed were called out, and performed cheerfully the guard and patrol duties assigned them.

An order was issued by Colonel Viall of Lee County, aid-de-camp to the governor, and directed to Colonel Weaver, instructing him to take command of the entire militia forces of the county and to put as many men on duty on the border as he thought the public. safety required. One hundred mounted men and two commissioned officers were detailed by the colonel and assigned to duty along the south line of the county, witlı instructions to patrol the roads day and night. 'Twenty-five men were detailed to do duty at the county seat and instructed to arrest every suspicious looking stranger that could be found in the vicinity. The same instructions were given to the troops on the border and the number of arrests that have been made from time to time since the order was issued, attests to the faithfulness with which it has been obeyed. Over one hundred persons have been arrested and turned back to Missouri at one post (Savannah). Ceaseless vigilance was the order of the day. A chain of couriers was appointed reaching to every school district in the border townships and every precantion taken to guard against surprise.

On the evening of October 21, 1864, a courier arrived at my place of business from Pulaski, with the intelligence that a body of twenty-five mounted men had been seen that morning, some three or four miles from Milton in Van Buren County. Some forty men were immediately mounted on horsehack, many of them "pressed" for the occasion, and started in the direction of Milton, fifteen miles distant, under the com- 
mand of Colonel Weaver. On arriving at Pulaski we learned that a scouting party had been sent out, leaving instructions to detain at $\mathrm{Pu}$ laski any forces that might arrive, until a courier from the scouting party should return with "tidings" from the scouts. 'This precaution was thought necessary as the raiders might possibly be moving westward but south of us. A scout soon arrived bringing the intelligence that they had encamped six miles south of Milton. We moved on rapidly to Milton where we found the militia of Troy, Pulaski and other parts of the county with the forces in the vicinity awaiting our arrival. Here we found and conversed with a lady at whose house they had taken breakfast that morning, who confirmed the statement of the number. But they had committed no depredations that we could hear of, except that they had taken some man prisoner whom they kept very closely, not suffering him to speak to the lady nor anyone else. We found othicr persons who had seen them and knew they were encamped at or near the house of $\mathrm{Mr}$. Billips.

The column being mounted again moved cautiously south, until within a quarter of a mile of Billips' house, they dismounted and, groping their way cautiously through the thick brushwood, surrounded the house and barn. So cautiously was the whole thing done that the dogs were not aroused until the men were at the doors. And then such a "yelping" of dogs was never heard in any other place except Missouri, or some other state where "niggers" and dogs are "household gods."

The inmates of the house were aroused. From them we learned that twenty-five men had encamped there in the evening, fed their horses, and after getting supper left about 9 o'clock in the evening. It was now nearly daylight. The command was again mounted and started in pursuit. But with some nine hours the start of us it was impossible to overtake them. Their tracks indicated that they had divided into small squads, taking as many different roads. We scoured the country for some twenty miles in Missouri and failing to find them, returned "every man to his tent." From that time until the evening of November 7 we had comparative quiet. But the number of strangers constantly passing and attempting to pass through the county kept our fears constantly aroused lest the scattered fugitives from Price's army should concentrate somewhere near the border and make another raid for pillage and murder.

On November 7 six persons came into the county from the east, traveling in pairs. Two of them stopped at the house of Mr. Hendricks, and in a rude, boisterous manner demanded something to eat. The lady declining to get dinner for them they helped themselves to what they could find in the cupboard and left. They made their way to the house of Mr. Gore and put up for the night. Thomas Duffield, William Wallace, and his son John Wallace, learning that they were suspicious looking characters and that they had stopped at Gore's, resolved to arrest them. 'The militia at 'Troy had been apprised of the strangers and were collect- 
ing for the purpose of arresting them. But Duffield and the two Wallaces believed that they could arrest them, and proceeded to the house. William Wallace entered the house and leveling his gun ordered them to surrender. The two inen, affecting a willingness to surrender and stepping into another room, almost instantly returned and with a revolver in each hand commenced firing. The older Wallace was killed almost instantly. The young man now rushed in and received some seven or eight shots. The men now attempted to run out but were met by Duffield whom they struck a heavy blow with a pistol, knocking him down, leaped over him, and after turning to fire on him, broke and run. Duffield was stunned with the blow, and young Wallace had fallen on him, which so encumbered him that it was difficult to return the fire. But disengaging himself as best he could he drew up and fired at one of them as he ran off. The fellow fell at the crack of the gun, but recovered and ran again. The militia from Troy arrived shortly after. Pursuit was made, but in the darkness the men escaped. Young Wallace still survives. His sufferings have been intense, but he bears it with the patience and fortitude of an old soldier. William Wallace was a good citizen, loved and respected by his neighbors. The lives of ten thousand such ruffians as those who killed him would not atone for his.

'line militia captured their horses and equipment. 'Their saddle pockets were filled with powder, balls, percussion caps, bullet molds, and horseshoe nails. Everything about their equipage indicated that they were Rebel bushwhackers or Confederate soldiers. In the hat of one was found a recruiting commission issued from the headquarters of Shelby's division of Price's army, and directed to Captain West with instruction to enforce the conseript law in Audrain, Adair, and Howard counties of Missouri.

'The news of Wallace's death reached Bloomficld in a very short time after it occurred. The militia was called out. The roads were patroled and guarded in every direction. Quite a number of strangers had been seen during the day in different parts of the county. Many believed that an attack was contemplated the next day, the day of the presidential election.

For the purpose of a rousing the whole county to vigilance, in the absence of a piece of artillery, I ordered the firing of an anvil. Alfred Rudd, formerly of Company G, Second Iowa Infantry, while discharging that duty received a most dangerous wound by the bursting of the anvil. He will be crippled for many months, perhaps for life. He has served his country faithfully and it would be but justice for the state to remunerate him, if not for his suffering, for loss of time.

On the morning of November 8 two young men were arrested, who upon examination confessed that they belonged to the gang of six men who came into the county the day before, and that the men who had killed Wallace were also two of their number; they stated that they, 
with a number of others, had been conscripted by West; that they had attempted to get to Price who was retreating; that West and his conscripts being cut off by the Union forces had disbanded; that afterwards West with six others got together and determined to get out of Missouri through Iowa. One of their number turned back in Missouri. The remaining six came to the Des Moines River and separated in pairs. West and his companion, Bob Chalk, were going to winter near the city of Des Moines. Zack Poor and his brother were going to Texas, and these two, Mark Sharon and William Mason, were going to Nebraska.

Other arrests were made from time to time, until we had at one time in jail thirteen as villainous looking scoundrels as ever went unhung. Two United States detectives came along, and being arrested and confined with the prisoners, obtained much information of value to us in regard to the future movements in contemplation by the bands of scoundrels who have infested northern Missouri since the rebellion. The prisoners were all sent to Missouri and placed in the hands of the proper authorities. Nine "contraband" horses with their equipments have been captured by the militia and sold by your order.

The vigilance of the militia stationed on the leading thoroughfares of the county, and the scouting parties patroling in every direction, has had the effect to turn the travel from Missouri east and west of our county. I have no doubt but large numbers of Rebels are now quietly wintering in Iowa, with a view of recruiting their horses and recuperating themselves preparatory to a concentration at some point in the spring. Our people should not release their vigilance because the danger has seemed to have passed by, but watch closely the movements of every stranger. We should know who they are and where they came from. A good, loyal man will not take offense when he knows that our inquiries are intended for the public safety, and if he is not loyal to his heart's core, no matter if he does take offense. Every loyal man along the southern border, in addition to the arms distributed by the state, should have at least one good revolver, and have it with him "omnipresent," so that he may be ready at any moment to meet a dashing raid, though it might come like a spark from smitten steel, and not have to run a half mile to his house and unlock a trunk to get it, and then stop to load it. There is no safety but in "eternal vigilance."

${ }^{4}$ S. A. MOORE, Lieut.-Col, and A. D. C.

4Samuel A. Moore was born in Lawrenceburg, Indiana, December 17, 1821, and died at Bloomfield, Iowa, Februatry 6,1905 . He was a newspaper man, a member of the Indiana Legislature in 1850 , removed to Davis County, lowa, in 1853 , farmed for a time, and was county judge from 1855-7. He entered mercantile business, but in 1861 enlisted and became captain of Company G, Second Iowa Infantry, and was severely wounded at Fort Donelson. He later became lientenant-colonel of the Forty-fifth Iowa Infantry. He was state senator in 1804-6, postmaster at Bloomfield from 1875 to 1883 , representative in 1902 , and sergeant-at-arms of the House in 1904. He was an eloquent speaker and a popular citizen.-Elitor. 
Copyright of Annals of Iowa is the property of State of Iowa, by \& through the State Historical Society of Iowa and its content may not be copied or emailed to multiple sites or posted to a listserv without the copyright holder's express written permission. However, users may print, download, or email articles for individual use. 